\title{
Preliminary enviromagnetic comparison of the moss, lichen, and filter fabric bags to air pollution monitoring
}

\author{
HANNA SALO
}

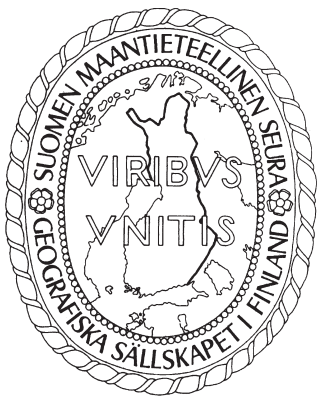

Salo, Hanna (2014). Preliminary comparison of the suitability of three sampling materials to air pollution monitoring. Fennia 192: 2, pp. 154-163. ISSN 17985617.

Air quality and anthropogenic air pollutants are usually investigated by passive biomonitoring, which utilizes native species. Active biomonitoring, instead, refers to the use of transplants or bags in areas lacking native species. In Finland, the standardized moss bag technique SFS 5794 is commonly applied in active monitoring but there is still a need for simpler and labor-saving sample material even on the international scale. This article focuses on a preliminary comparison of the usability and collection efficiency of bags made of moss Sphagnum papillosum, lichen Hypogymnia physodes, and filter fabric (Filtrete ${ }^{\mathrm{TM}}$ ) in active biomonitoring of air pollutants around an industrial site in Harjavalta, SW Finland. The samples are analyzed with magnetic methods (i.e. magnetic susceptibility, isothermal remanent magnetization, hysteresis loop and hysteresis parameters) highly suitable as a first-step tool for pollution studies.

The results show that the highest magnetic susceptibility of each sample material is measured close to the industrial site. Furthermore, moss bags accumulate more magnetic material than lichen bags which, on the contrary, perform better at further distances. Filtrete ${ }^{\mathrm{TM}}$ bags are tested only at $1 \mathrm{~km}$ sites indicating a good accumulation capability near the source. Pseudo-single-domain (PSD) magnetite is identified as the main magnetic mineral in all sample materials and good correlations are found between different bag types. To conclude, all three materials effectively accumulate air pollutants and are suitable for air quality studies. The results of this article provide a base for later studies which are needed in order to fully determine a new, efficient, and easy sample material for active monitoring.

Keywords: Harjavalta (Finland), air pollution, active monitoring, bag technique, magnetic methods, material comparison

Hanna Salo, Department of Geography and Geology, University of Turku, Fl20014 Turku,Finland. E-mail: hanna.salo@utu.fi

\section{Introduction}

Air quality impacts on the health and well-being of people and environment on all geographical and temporal scales (Fenger 1999). Biomonitoring is a common way to study air quality and anthropogenic air pollution, and it is defined as the use of organisms and biomaterials to obtain information on certain characteristics of the biosphere (Wolterbeek 2002). Traditional indicator species, especially leaves and needles, have been recently in- vestigated successfully with easy, fast, cost-effective, and usually non-destructive magnetic methods (e.g. Lehndorff et al. 2006, Mitchell \& Maher 2009). The research method of environmental magnetism (also enviromagnetics) has found various applications e.g. in geography, archaeology, and climatology throughout the world after it separated as its own discipline in the 1980s. Even though lichens and mosses are excellent bioaccumulators and commonly used in biomonitoring since the 1970s (Szczepaniak \& Biziuk 2003), they 
have been utilized in few enviromagnetic studies so far (e.g. Jordanova et al. 2010, Fabian et al. 2011, Salo et al. 2012, Chaparro et al. 2013).

Biomonitoring can be passive or active. According to Szczepaniak and Biziuk (2003), passive biomonitoring refers to the use of native plants whereas active monitoring includes the exposure of well-defined species as transplants or bags. The latter exposure method is especially valuable in polluted areas suffering for the absence of native species (i.e. moss or lichen desert). Furthermore, active monitoring has several advantages: the initial element concentrations and exposure periods are well-known (Ares et al. 2012), the transplants collection efficiency is greater for most elements (Adamo et al. 2003), and they may be positioned flexibly without the fear of vandalism since they are rather inconspicuous. As pointed out by Fernández and Carballeira (2000), native plants may yield results underestimating the deposition of heavy metals because of the possible adaptation of material to its surroundings, and therefore, active monitoring is the most accurate method.

The bag technique has been applied for both lichens and mosses (e.g. Adamo et al. 2003, Culicov \& Yurukova 2006), although moss bags are more familiar. However, many moss bag techniques have comprised due to the lack of internationally standardized method making the result comparison harder. A wide range of lichen and moss species used for active monitoring has been reported in research papers. Stated by Ares et al. (2012), the most suitable species for moss bag technique come from the genus Sphagnum. These species have an excellent water retention and high cation-exchange capacity (Little \& Martin 1974). In Finland, the moss bag technique was standardized in the 1990s, and the recommended species is primarily Sphagnum papillosum and secondarily $S$. girgensohnii. As for lichens, widespread $\mathrm{Hy}$ pogymnia physodes is used also as transplants because it is moderately sensitive to heavy metals and $\mathrm{SO}_{2}$ (Hauck \& Huneck 2007). In Turku (SW Finland), magnetic biomonitoring of both native and transplanted lichen $H$. physodes proved to be functional, although transplants near the city center in the lichen desert area attracted birds (Limo 2010, Salo et al. 2012).

The purpose of this study is to preliminary compare the usability and collection efficiency of $S$. papillosum moss bags (standardized method in Finland) and $H$. physodes lichen bags in magnetic monitoring of air pollutants. Also filter fabric (Fil- trete $^{T M}$ ) bags are tested at the most heavily polluted sites. The bags were exposed to air pollutants at the limited number of sample sites around an industrial point source in Harjavalta (SW Finland) in the fall 2011 for a collection period of six months.

\section{Study area, materials and methods}

\section{Study area}

The study area Harjavalta $\left(61^{\circ} 19^{\prime} \mathrm{N}, 22^{\circ} 19^{\prime} \mathrm{E}\right)$ is located in SW Finland (Fig. 1a) at the southern boreal coniferous zone along the Kokemäenjoki River and the Pori-Helsinki highway and railroad. Primarily the Industrial Park, a cluster of heavy metal and chemical industries within $1 \mathrm{~km}$ from the town centre, produces copper, sulfuric acid, nickel and special chemicals, as well as fertilizers by refining $\mathrm{Cu}$ - and $\mathrm{Ni}$-concentrates and other raw materials. The Industrial Park is regarded as the main emission source in the town, but air pollutants can originate also from two foundries, traffic, and domestic heating systems. The fly-ash load from the $\mathrm{Cu}-\mathrm{Ni}$ smelter's pipe is usually held as the most significant pollution source, but various dustproviding sources, e.g. concentrate or slag handling, are more important at short distances (Salo \& Mäkinen 2014). Common air pollutants are sulfur dioxides, dust, and heavy metals such as $\mathrm{Cu}$, $\mathrm{Ni}, \mathrm{Zn}, \mathrm{Pb}, \mathrm{As}, \mathrm{Cd}$, and Hg (Jussila 2009). In 2011, the average annual emissions of $\mathrm{SO}_{2}$ and total dust were $2970 \mathrm{t}$ and $6.8 \mathrm{t}$, respectively. Over 300,000 t of Cu-slag and over 150,000 t of granulated Nislag are formed annually as by-products from the smelting. Separate slag heaps located nearby are an additional dust emission source when they remain uncovered or their edges dry out (Nieminen et al. 2002).

\section{Bag preparation and sampling}

The moss Sphagnum papillosum and lichen Hypogymnia physodes were chosen for comparison. The moss bags were prepared after the standard SFS 5794 (Finnish Standards Association 1994), except for the longer exposure time. The green parts of the moss were collected from a non-polluted bog in Honkajoki. After removing the pieces of other vegetation and litter, the moss was washed in $\mathrm{HCl}$ and rinsed with deionized $\mathrm{H}_{2} \mathrm{O}$ in the laboratory. The lichens of about 3-4 cm diameter were 

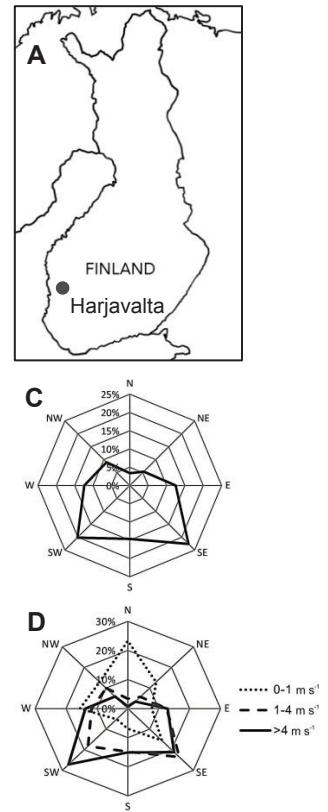

$\triangle$ Moss, lichen \& filter fabric

Moss \& lichen

Kokemäenjoki River
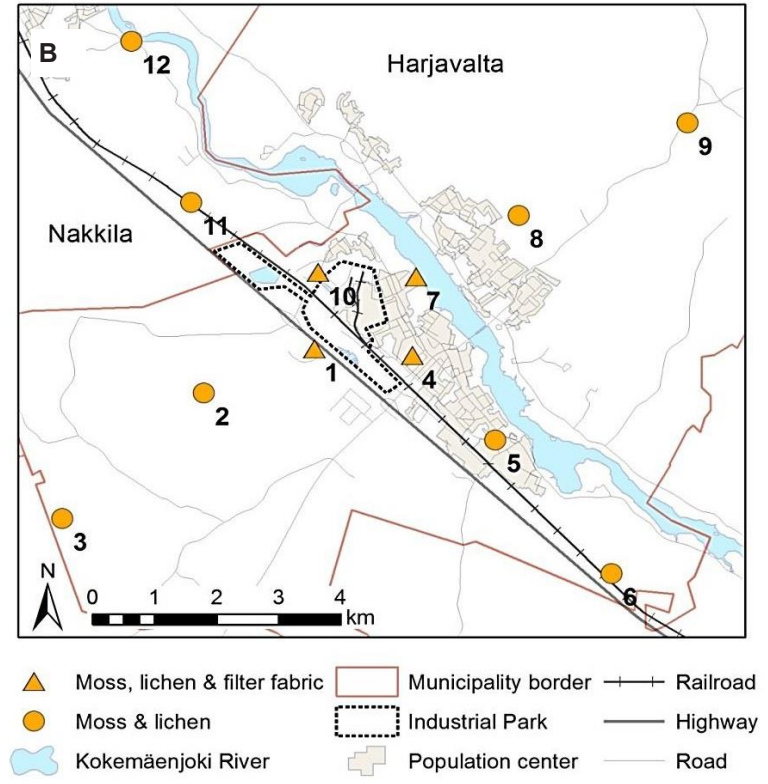

Fig. 1. The study area, Harjavalta, is situated in SW Finland (a). The sampling bags were placed at the distances of 1,3 , and $6 \mathrm{~km}$ from the industrial point source (b) Wind roses indicate prevailing wind directions (c) and strengths (d) during the sampling period in fall 2011. (C) National Land Survey of Finland 2010). collected with underlying bark from Pinus silvestris trunks between the heights of $50-200 \mathrm{~cm}$ in the rural area of Kemiö. In addition, a synthetic filter fabric (Filtrete ${ }^{\mathrm{TM}}$ ) used e.g. in ventilation windows was preliminary tested. The filter fabric has an electrical charge, which effectively traps small particles such as pollen and air pollutants, and onesided plastic net, which protects it from rainwater. The plastic net was removed before the fabric was ripped in smaller pieces.

Each sample material was placed in a polyamide net (with $0.64 \mathrm{~cm}^{2}$ mesh) and closed with a cotton thread. One part of a material was stored as a non-exposed control sample and its magnetic results were subtracted from the data. The bags were transported to the field and back to the laboratory in sealed plastic bags. In the laboratory, the exposed bags from the same sampling site were combined into one composite sample according to the material type. As for lichen samples, the bark pieces were removed. The composite samples were dried to constant weight at $\mathrm{T}<40{ }^{\circ} \mathrm{C}$ and homogenized. Approximately 2/3 of moss and lichen samples were ground by Retsch PM100 planetary ball mill (500 rpm, $30 \mathrm{~s}$ for moss; $300 \mathrm{rpm}, 10 \mathrm{~s}$ for lichen) equipped with a $\mathrm{ZrO}_{2}$ (zirconium oxide) grinding bowl and balls. Ground material was used for magnetic susceptibility analyses and unground material for IRM and hysteresis measurements. All the tools used in a sample preparation were washed and finally rinsed with deionized $\mathrm{H}_{2} \mathrm{O}$.

The moss, lichen, and Filtrete ${ }^{\mathrm{TM}}$ bags (Fig. 2) were exposed to air pollutants around the Industrial Park for a sampling period of six months (181185 days) in the fall 2011. For the moss bags, the collection period was longer than notified in the standard. It was a compromise made to enable the sample material comparison by ensuring enough accumulation time for the lichen and Filtrete $^{\mathrm{TM}}$ bags. The background level for pollutants was determined from the southern shore of Sääksjärvi lake locating $17.5 \mathrm{~km}$ in NE from Harjavalta. The bags were hung in trees at a height of $2.5-3 \mathrm{~m}$ from the ground at the approximate distances of 1 , 3 , and $6 \mathrm{~km}$ from the $\mathrm{Cu}-\mathrm{Ni}$ smelter's pipe, which acted as the starting point of four transects (SW, SE, NE, NW) (Fig. 1b). Five moss bags and three lichen bags were placed in all sample sites while two Filtrete $^{\mathrm{TM}}$ bags were tested only at $1 \mathrm{~km}$ and background sites. However, the moss bags were lost from sample site 2 . The prevailing wind directions 

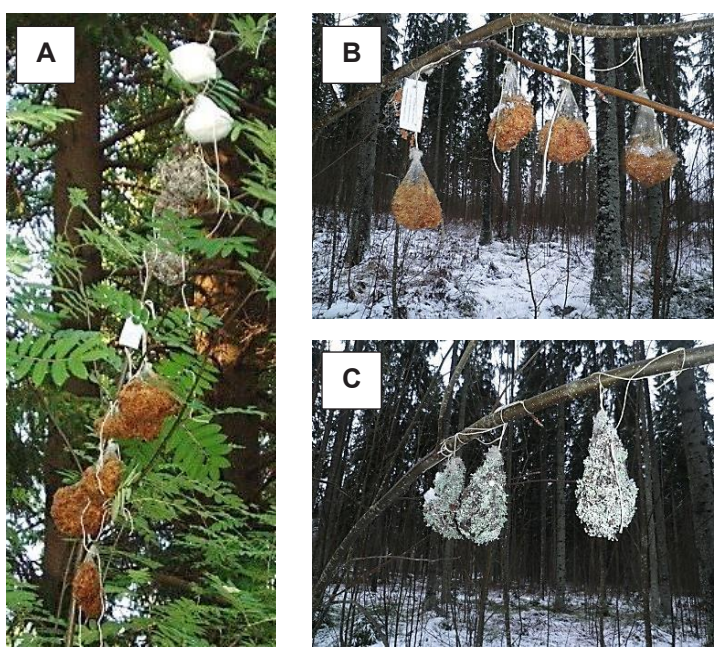

Fig. 2. The bags of moss Sphagnum papillosum, lichen $\mathrm{Hy}_{\text {- }}$ pogymnia physodes, and white filter fabric (Filtrete ${ }^{\mathrm{TM}}$ ) were exposed at background and $1 \mathrm{~km}$ sites (a), while only moss (b) and lichen (c) bags were exposed at 3 and $6 \mathrm{~km}$ sites.

and the strongest winds $\left(>4 \mathrm{~m} \mathrm{~s}^{-1}\right)$ in the study area were from SE-S-SW during the sampling period (Fig. 1c, d). The lithogenic contribution to the bags is considered minor because the ground was covered either with vegetation or snow during the sampling period.

\section{Magnetic methods}

Magnetic susceptibility (volume- or mass-specific) represents the concentration of magnetic minerals in a sample, and measures the ease with which a material can be magnetized (Thompson \& Oldfield 1986). Mass-specific susceptibility $\left(\chi \times 10^{-8}\right.$ $\mathrm{m}^{3} \mathrm{~kg}^{-1}$ ) was measured at the Department of Geography and Geology, University of Turku, using a Bartington MS2B dual-frequency $(0.47$ and 4.7 $\mathrm{kHz}$ ) susceptibility meter. A standard $1 \mathrm{~cm}^{3}$ plastic container was tightly filled with sample material (moss, lichen, filter fabric). The mass-specific susceptibility of each sample is the average value of five low frequency measurements. The validity of the susceptibility measurements was confirmed by preparing two subsamples from the non-exposed control, background, and exposed bag samples. In the case of Filtrete ${ }^{\mathrm{TM}}$ bags, the whole material was measured and the average value was calculated.
Magnetic mineralogy, concentration, and grain sizes of a sample can be investigated with isothermal remanent magnetization (IRM), hysteresis loop and hysteresis parameters. IRM acquisition curves and hysteresis loops for selected samples were measured at the Department of Physics, University of Helsinki, using a Princeton Vibrating Sample Magnetometer (VSM) Model 3900. Hysteresis parameters, saturation magnetization $\left(M_{S}\right)$, saturation remanence $\left(M_{R S}\right)$, and coercive force $\left(\mathrm{H}_{\mathrm{C}}\right)$ were obtained after paramagnetic slope correction. Coercivity of remanence $\left(\mathrm{H}_{\mathrm{CR}}\right)$ was determined from direct current (D.C.) demagnetization of saturation remanence. Hysteresis loops and IRM curves were measured up to $1 \mathrm{~T}$ at room temperature.

\section{Statistical methods}

The magnetic data were statistically analyzed with IBM SPSS Statistics version 20. The magnetic susceptibilities of each sample material followed the normal distribution. Thus, the comparison of susceptibilities between different bag types was done by paired samples t-test. The null hypothesis $\left(\mathrm{H}_{0}\right)$ was that the mean difference between paired observations is zero. The linear relationship between magnetic susceptibilities obtained by each sample material was investigated with the Pearson correlation coefficients $(r)$ and the associated level of significance (sig.). Background samples were excluded from the analyses.

\section{Results}

\section{Magnetic susceptibility and correlations}

Magnetic susceptibility varies between $-1.5 \times 10^{-8}$ and $127.3 \times 10^{-8} \mathrm{~m}^{3} \mathrm{~kg}^{-1}$ for the moss bags, and between $0.7 \times 10^{-8}$ and $77.2 \times 10^{-8} \mathrm{~m}^{3} \mathrm{~kg}^{-1}$ for the lichen bags (Table 1). The susceptibilities of the Filtrete $^{\mathrm{TM}}$ bags from $1 \mathrm{~km}$ sampling sites are between $8.4 \times 10-8$ and $132.1 \times 10-8 \mathrm{~m} 3 \mathrm{~kg}-1$. The background samples have susceptibilities of $1.0 \times 10^{-8}$, $3.4 \times 10^{-8}$, and $0.4 \times 10^{-8} \mathrm{~m}^{3} \mathrm{~kg}^{-1}$, respectively. Furthermore, the susceptibility of ten clean filter fabric samples range between $-2.3 \times 10^{-8}$ and -0.9 $\times 10^{-8} \mathrm{~m}^{3} \mathrm{~kg}^{-1}$ with the average value of $-1.4 \times 10^{-8}$ $\mathrm{m}^{3} \mathrm{~kg}^{-1}$ and standard deviation of 0.5 .

For moss and lichen bags, the highest and lowest susceptibility values are measured at 1 and 6 
$\mathrm{km}$ sites. A trend of decreasing susceptibility with increasing distance from the $\mathrm{Cu}-\mathrm{Ni}$ smelter's pipe is distinguished in each transect. The background level is reached typically at $6 \mathrm{~km}$, except for lichen bags in NW line. Generally, the moss bags yield higher susceptibilities at $1 \mathrm{~km}$ sites, while the lichen bags at 3 and $6 \mathrm{~km}$ sites. Paired samples t-test indicates that the means of susceptibilities $(19.2 \mathrm{x}$ $10^{-8}$ and $15.9 \times 10^{-8} \mathrm{~m}^{3} \mathrm{~kg}^{-1}$, respectively) between moss and lichen bags are equal (sig. >0.05). Thus, the obtained susceptibilities are statistically similar.

Filter fabric bags have magnetic susceptibilities close to the same concentration as moss and lichen bags. The means of susceptibilities from $1 \mathrm{~km}$ sites between moss and Filtrete ${ }^{\mathrm{TM}}$ bags $\left(48.2 \times 10^{-8}\right.$ and $\left.44.6 \times 10^{-8} \mathrm{~m}^{3} \mathrm{~kg}^{-1}\right)$, and lichen and Filtrete ${ }^{\mathrm{TM}}$ bags $\left(33.8 \times 10^{-8}\right.$ and $\left.44.6 \times 10^{-8} \mathrm{~m}^{3} \mathrm{~kg}^{-1}\right)$ are equal (sig. $>0.05$ ) in the paired samples t-test. The highest susceptibility for Filtrete $\mathrm{TM}^{\mathrm{M}}$ bags, and also for moss and lichen bags, is found from NW line at sample site 10 . Here, however, the lichen bags have the lowest value $\left(77.2 \times 10^{-8} \mathrm{~m}^{3} \mathrm{~kg}^{-1}\right)$, whereas the other two bag types have susceptibilities close to $130 \times 10^{-8} \mathrm{~m}^{3} \mathrm{~kg}^{-1}$.

A linear relationship is found between the susceptibilities of different sample types (Fig. 3). Pearson's correlation coefficient $(r)$ for the susceptibilities of moss and lichen bags is 0.982 . Furthermore, moss and filter fabric bags have a very strong correlation of 1.000 while lichen and filter fabric bags have a correlation of 0.976 . The former two correlations are significant at the 0.01 level while the latter is significant at the 0.05 level.

Table 1. The location of sample sites and magnetic parameters (mass-specific susceptibility $\left(\chi \times 10^{-8} \mathrm{~m}^{3}\right.$ $\left.\mathrm{kg}^{-1}\right)$, saturation remanence $\left(M_{\mathrm{RS}}\left(\mathrm{mAm} \mathrm{kg}^{-1}\right)\right)$, saturation magnetization $\left(M_{\mathrm{S}}\left(\mathrm{mAm} 2 \mathrm{~kg}^{-1}\right)\right)$, coercivity of remanence $\left(H_{C R}(m T)\right)$, coercive force $\left(H_{C}(m T)\right)$, and ratios of $M_{R S} / M_{S}$ and $\left.H_{C R} / H_{C}\right)$ for moss, lichen, and filter fabric bags.

\begin{tabular}{|c|c|c|c|c|c|c|c|c|}
\hline ID & Direction, distance (m) & $\chi$ & $\mathbf{M}_{\mathrm{RS}}$ & $\mathbf{M}_{\mathbf{S}}$ & $\mathbf{M}_{\mathrm{RS}} / \mathbf{M}_{\mathrm{S}}$ & $\mathbf{H}_{\mathrm{CR}}$ & $\mathbf{H}_{\mathbf{C}}$ & $\mathbf{H}_{\mathrm{CR}} / \mathbf{H}_{\mathrm{C}}$ \\
\hline \multicolumn{9}{|c|}{ Moss Sphagnum papillosum } \\
\hline 1 & SW, 1060 & 16.2 & 1.09 & 15.50 & 0.07 & 33.22 & 6.60 & 5.0 \\
\hline 2 & SW, 3060 & - & & & & & & \\
\hline 3 & SW, 6050 & 1.0 & & & & & & \\
\hline 4 & SE, 1030 & 24.1 & 0.62 & 5.94 & 0.10 & 41.02 & 8.25 & 5.0 \\
\hline 5 & SE, 3010 & 7.5 & 0.087 & 1.94 & 0.04 & 32.77 & 11.92 & 2.7 \\
\hline 6 & SE, 5940 & -1.5 & & & & & & \\
\hline 7 & NE, 980 & 25.3 & 1.47 & 17.95 & 0.08 & 36.04 & 7.86 & 4.6 \\
\hline 8 & $\mathrm{NE}, 2840$ & 2.1 & & & & & & \\
\hline 9 & NE, 6070 & 0.8 & & & & & & \\
\hline 10 & NW, 1040 & 127.3 & 9.22 & 83.54 & 0.11 & 31.07 & 9.06 & 3.4 \\
\hline 11 & NW, 3390 & 5.0 & 0.56 & 5.20 & 0.11 & 28.96 & 9.63 & 3.0 \\
\hline 12 & NW, 5960 & 2.9 & 0.69 & 4.60 & 0.15 & 29.92 & 16.38 & 1.8 \\
\hline BKGD & NE, 17600 & 1.0 & & & & & & \\
\hline \multicolumn{9}{|c|}{ Lichen Hypogymnia physodes } \\
\hline 1 & SW, 1060 & 13.1 & 0.84 & 9.72 & 0.09 & 36.60 & 8.66 & 4.2 \\
\hline 2 & SW, 3060 & 6.4 & 0.64 & 6.59 & 0.10 & 38.04 & 10.16 & 3.7 \\
\hline 3 & SW, 6050 & 3.1 & & & & & & \\
\hline 4 & $\mathrm{SE}, 1030$ & 15.3 & 1.37 & 14.07 & 0.10 & 36.12 & 9.01 & 4.0 \\
\hline 5 & SE, 3010 & 12.4 & 0.87 & 9.50 & 0.09 & 34.47 & 9.29 & 3.7 \\
\hline 6 & SE, 5940 & 1.4 & & & & & & \\
\hline 7 & NE, 980 & 29.7 & 2.00 & 20.46 & 0.10 & 34.65 & 8.65 & 4.0 \\
\hline 8 & NE, 2840 & 5.2 & & & & & & \\
\hline 9 & NE, 6070 & 0.7 & & & & & & \\
\hline 10 & NW, 1040 & 77.2 & 9.62 & 90.91 & 0.11 & 30.54 & 9.34 & 3.3 \\
\hline 11 & NW, 3390 & 8.1 & 0.91 & 8.71 & 0.10 & 40.15 & 10.22 & 3.9 \\
\hline 12 & NW, 5960 & 9.2 & & & & & & \\
\hline BKGD & NE, 17600 & 3.4 & & & & & & \\
\hline \multicolumn{9}{|c|}{ Filter fabric (Filtrete $\left.{ }^{\mathrm{TM}}\right)$} \\
\hline 1 & SW, 1060 & 8.4 & - & - & - & - & - & - \\
\hline 4 & SE, 1030 & 19.6 & 2.90 & 30.22 & 0.10 & 34.11 & 8.32 & 4.10 \\
\hline 7 & NE, 980 & 18.2 & 3.01 & 28.81 & 0.10 & 35.26 & 8.90 & 3.96 \\
\hline 10 & NW, 1040 & 132.1 & 23.64 & 195.80 & 0.12 & 34.75 & 10.77 & 3.23 \\
\hline BKGD & NE, 17600 & 0.4 & & & & & & \\
\hline
\end{tabular}



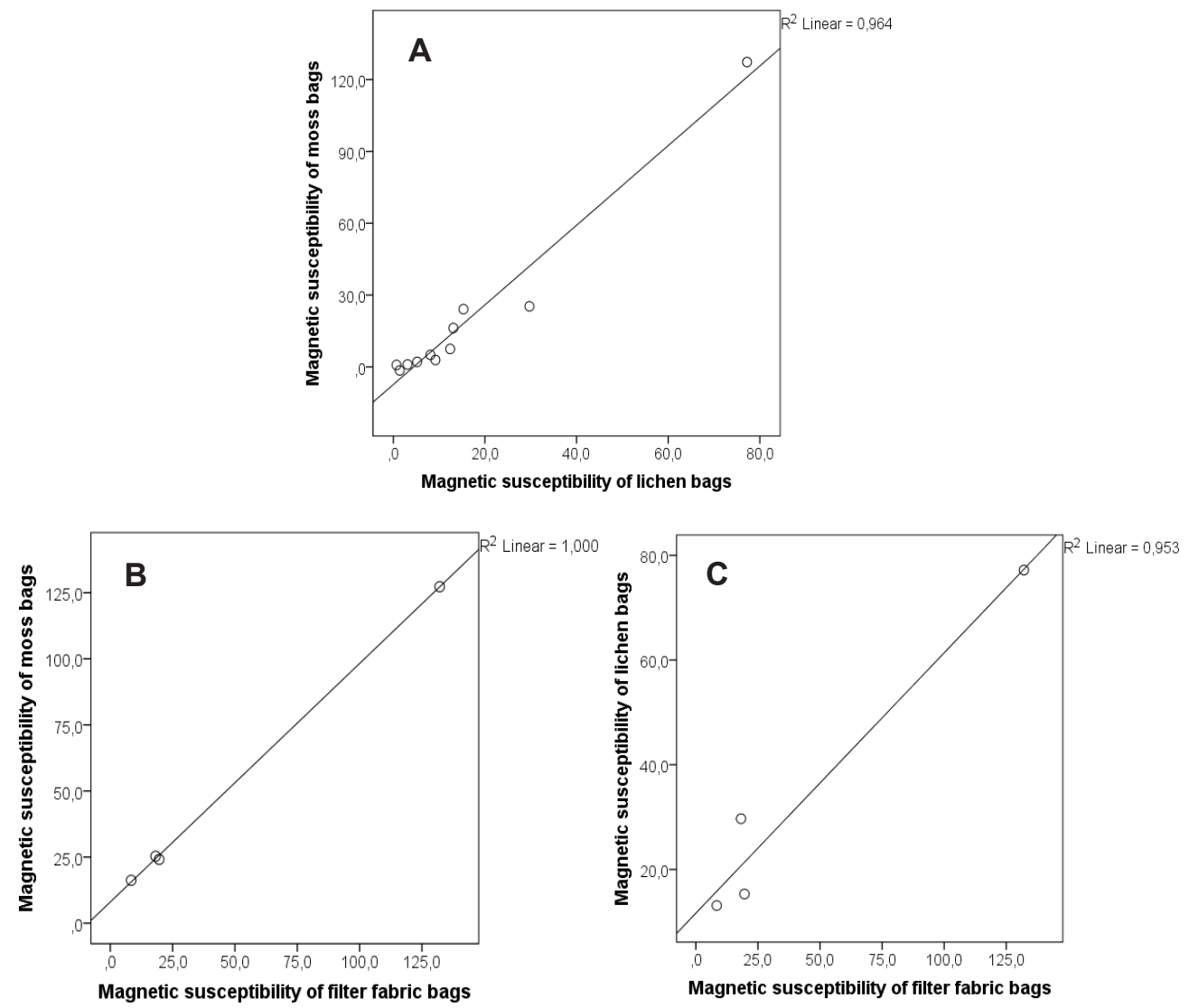

Fig. 3. Linear relationship exists between magnetic susceptibilities of moss and lichen bags (a), moss and filter fabric bags (b), as well as lichen and filter fabric bags (c).

\section{Magnetic mineralogy}

Hysteresis loops and IRM acquisition curves (Fig. 4a) rapidly reach saturation at $0.2 \mathrm{~T}$. Furthermore, the coercivities and coercivities of remanence of the samples range roughly between 7-11 mT, and 29-41 mT, respectively (Table 1). These parameters indicate that low-coercivity magnetite is the dominant magnetic mineral in the samples. Hysteresis ratios of $\mathrm{M}_{\mathrm{RS}} / \mathrm{M}_{\mathrm{S}}$ and $\mathrm{H}_{\mathrm{CR}} /$ $\mathrm{H}_{\mathrm{C}}$ plotted in the Day diagram show magnetite to fall in the pseudo-single-domain (PSD) region closer to the mixing line for single-domain (SD)multidomain (MD) grains than for superparamagnetic (SP)-SD grains (Fig. 4b).

\section{Discussion and conclusions}

In this study, the moss Sphagnum papillosum and lichen Hypogymnia physodes were pretreated differently before the bag preparation. The moss was devitalized by acid-washing for obtaining homogenous material and to even out the initial element levels (Finnish Standards Association 1994, Ares et al. 2012), while native lichen without pretreatments was used. According to Adamo et al. (2007), the accumulation performance of materials is not drastically altered in the devitalization. Furthermore, devitalized Sphagnum species accumulate trace metals passively due to their excellent ionexchange properties (Adamo et al. 2003). Howev- 
A

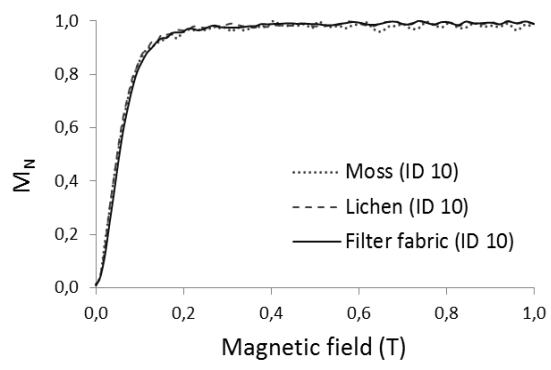

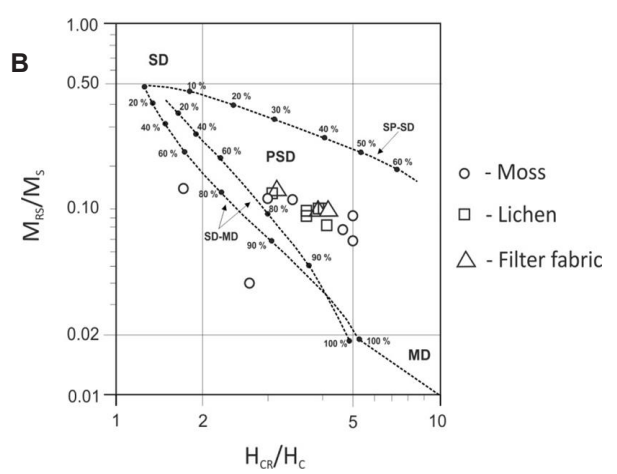

Fig. 4. IRM acquisition curves ( $\mathrm{MN}$ - magnetization $\left(\mathrm{Am}^{2} \mathrm{~kg}^{-1}\right)$ normalized by max. value) (a), and Day plot-diagram (b) for different bag types. In the Day plot, the single-domain (SD), pseudo-single-domain (PSD), and multi-domain (MD) boundaries for grains and mixing lines are shown after Dunlop (2002).

er, the elemental composition of the natural lichen (and moss) may differ even though it is collected from the same remote area (Frati et al. 2005), and, therefore, the bag or transplant technique with devitalized species gives more accurate results for the air contamination. The moss bag preparation is consequently the most laborious whereas the collection of lichen is slow and requires large areas in order to obtain enough material for the bags. Hence, artificial, ready-to-use -material would be ideal; Filtrete ${ }^{\mathrm{TM}}$ does not require any special preparations or treatments.

In the case of moss and lichen bags, all transects in Harjavalta show decreasing magnetic susceptibilities with increasing distance from the Industrial Park. Similar patterns dominate studies both from Harjavalta and other industrial areas (e.g. Hanesch et al. 2003, Salo \& Mäkinen 2014). Susceptibilities in each sample type show great variations in $1 \mathrm{~km}$ distances with the highest values found at NW (site 10). This result from the circumstances during the accumulation period, i.e. site 10 is located in the prevailing wind direction. Overall, the magnetic results of moss and lichen samples indicate stronger accumulation of low-coercivity magnetite close to the Industrial Park. Previous studies about Harjavalta (e.g. Jussila 2009, Salo et al. 2012, Salo \& Mäkinen 2014) imply more intense pollution dispersal to the SE and NW from the industrial area along the prevailing wind directions and Kokemäenjoki River valley. The very same pattern can be distinguished in this study: susceptibility values are higher in SE and NW than in SW or NE at further distances. The species' capacity to accumulate and uptake given elements is affected by morphological and structural features (Cercasov et al. 2002, Culicov \& Yurukova 2006). For example, Loppi and Bonini (2000) found statistically significant (sig. <0.05) differences in concentrations for $\mathrm{Al}, \mathrm{B}, \mathrm{Fe}, \mathrm{Hg}, \mathrm{Pb}, \mathrm{Sb}$, and $\mathrm{Zn}$, with moss Hypnum cupressiforme retaining higher values than lichen Parmelia sulcata except for $\mathrm{Hg}$ and $\mathrm{Zn}$. Further, Adamo et al. (2007) reported higher element load in moss $H$. cupressiforme than lichen Pseudevernia furfuracea, with statistically significant differences for $\mathrm{Al}, \mathrm{Fe}$, and $\mathrm{Zn}$. This study at hand lacks chemical analyses which would make the element accumulation capacity estimations possible, but some differences can be seen in the Day plot-diagram (Fig. 4b): the magnetite grain sizes are slightly more dispersed in the moss bags than in the lichen or Filtrete ${ }^{\mathrm{TM}}$ bags. Maybe the structure of moss enables more wind to flow through the bag while smaller particles get trapped.

As for the comparison of moss and lichen bags' collection efficiency, presented by mass-specific susceptibilities in this study, the moss bags are more effective at $1 \mathrm{~km}$ sites in SE and especially NW (sites 4 and 10, respectively), while the lichen bags perform better at further distances of 3 and 6 $\mathrm{km}$ as well as background site. Location or wind conditions of individual site do not explain the difference in sites 4 and 10 since the bags were exposed together. Here, the $\mathrm{SO}_{2}, \mathrm{NOx}$, and/or heavy 
metal levels may have been high enough to deteriorate lichens accumulation capacity. According to Jussila et al. (1991), Hypogymnia physodes starts to perish when the pollutant level exceeds its tolerance. Moreover, $\mathrm{SO}_{2}$ is very harmful for most lichen species and may cause lichens to deteriorate and even die (Häffner et al. 2001). Lichen species are also more sensitive to gaseous air pollutants than mosses (Coskun et al. 2009). Mikhailova (2007), for example, has reported the decreased abundance of the epiphytic $H$. physodes around a copper smelter in the Middle Urals due to the $\mathrm{Cu}$ stress. Furthermore, the element contents of the lichen transplants vary with time, rather than increase linearly, because rainwater for instance removes particles from the lichen surfaces (Backor \& Loppi 2009). Adamo et al. (2003) instead have concluded that wet conditions improve lichens accumulation capacity. Nevertheless, the lichen transplants of $H$. physodes reach the balance with surrounding environment and the contents of native lichens within a time frame from 4-6 months (Palomäki et al. 1992), to 7 months (Pilegaard 1979) or 1 year (Mikhailova \& Sharunova 2008).

The comparison of accumulation capacity made by Adamo et al. (2007) between lichen bags, moss bags, and synthetic filters (quartz fiber and cationexchange) resulted in a very poor performance of artificial materials. The preliminary test with filter fabric (Filtrete ${ }^{\mathrm{TM}}$ ) gives promising results as for mass-specific susceptibility and weather tolerance in this article. The Filtrete ${ }^{\mathrm{TM}}$ bags work well near the emission source but their usability at further distances remains unknown. Moreover, they correlate perfectly with moss bags, but the small sample number impacts on the reliability of the results. This connection, however, is an encouraging indicator that Filtrete ${ }^{\mathrm{TM}}$ could be suitable substitute for moss bags: ready-to-use, effective, durable, and effortless.

To conclude, all three sample materials effectively accumulate air pollutants during the exposure period of six months and tolerate well different weather conditions. The results obtained with Filtrete $^{\mathrm{TM}}$ are interesting and favourable. Magnetic susceptibilities indicate that the lichen bags are more efficient accumulators at further distances than moss bags, whereas the situation is opposite near the emission source. Moss bags appear to be a better choice since high pollution levels, e.g. $\mathrm{SO}_{2}$, may deteriorate the accumulation capacity of the lichen and, thus, distort the results. Finally, these preliminary results of this article can be used in future studies for finding and/or developing a new, labor-saving, and effective material for active (magnetic) monitoring of air pollution.

\section{ACKNOWLEDGEMENTS}

This study was funded by the High Technology Foundation of Satakunta, and the Department of Geography and Geology, University of Turku. The comments of two anonymous referees and Joni Mäkinen for improving this manuscript are highly appreciated.

\section{REFERENCES}

Adamo P, Giordano S, Vingiani S, Castaldo Cobianchi R \& Violante P 2003. Trace element accumulation by moss and lichen exposed in bags in the city of Naples (Italy). Environmental Pollution 122: 1, 91-103. http://dx.doi.org/10.1016/S02697491(02)00277-4.

Adamo P, Crisafulli P, Giordano S, Minganti V, Modenesi P, Monaci F, Pittao E, Tretiach M \& Bargagli R 2007. Lichen and moss bags as monitoring devices in urban areas. Part II: Trace element content in living and dead biomonitors and comparison with synthetic materials. Environmental Pollution 146: 2, 392-399. http://dx.doi.org/10.1016/j.envpol.2006.03.047.

Ares A, Aboal JR, Carballeira A, Giordano S, Adamo P \& Fernández JA 2012. Moss bag biomonitoring: A methodological review. Science of the Total Environment 432, 143-158. http://dx.doi.org/10.1016/j. scitotenv.2012.05.087.

Backor M \& Loppi S 2009. Interactions of lichens with heavy metals. Biologia Plantarum 53: 2, 214222.

http://dx.doi.org/10.1007/s10535-009-0042-y.

Cercasov V, Pantelica A, Salagean M, Caniclia G \& Scarlat A 2002. Comparative study of the suitability of three lichen species to trace-element air monitoring. Environmental Pollution 119: 1, 129 139.

http://dx.doi.org/10.1016/S0269-7491(01)00170-1.

Chaparro MAE, Lavornia JM, Chaparro MAE \& Sinito AM 2013. Biomonitors of urban air pollution: magnetic studies and SEM observations of corticolous foliose and microfoliose lichens and their suitability for magnetic monitoring. Environmental Pollution 172, 61-69. http://dx.doi.org/10.1016/j.envpol.2012.08.006.

Coskun M, Steinnes E, Coskun M \& Cayir A 2009. Comparison of epigeic moss (Hypnym cupressiforme) and lichen (Cladonia rangiformis) as biomonitors species of atmospheric metal deposition. Bulletin of Environmental Contamination and Toxicology 82: 1, 1-5. http://dx.doi.org/10.1007/s00128-008-9491-9. 
Culicov OA \& Yurukova L 2006. Comparison of element accumulation of different moss- and lichen bags, exposed in the city of Sofia (Bulgaria). Journal of Atmospheric Chemistry 55: 1, 1-12. http:// dx.doi.org/10.1007/s10874-005-9002-x.

Dunlop DJ 2002. Theory and application of the Day plot (Mrs/Ms versus $\mathrm{Hcr} / \mathrm{Hc}) 1$. Theoretical curves and tests using titanomagnetite data. Journal of Geophysical Research 107: B3.

http://dx.doi.org/10.1029/2001JB000486.

Fabian K, Reimann C, McEnroe SA \& WillemoesWissing B 2011. Magnetic properties of terrestrial moss (Hylocomium splendens) along a northsouth profile crossing the city of Oslo, Norway. Science of the Total Environment 409: 11, 22522260.

http://dx.doi.org/10.1016/j.scitotenv.2011.02.018.

Fenger J 1999. Urban air quality. Atmospheric Environment 33: 29, 4877-4900.

http://dx.doi.org/10.1016/S1352-2310(99)00290-3 .

Fernández JA \& Carballeira A 2000. Differences in the responses of native and transplanted mosses to atmospheric pollution: a possible role of selenium. Environmental Pollution 110: 1, 73-78. http:// dx.doi.org/10.1016/S0269-7491(99)00278-X.

Finnish Standards Association 1994. Air protection. Bioindication. Moss bag method. Standard SFS 5794. pp. 3.

Frati L, Brunialti G \& Loppi S 2005. Problems related to lichen transplants to monitor trace element deposition in repeated surveys: a case study from Central Italy. Journal of Atmospheric Chemistry 52: 3, 221-230.

http://dx.doi.org/10.1007/s10874-005-3483-5.

Hanesch M, Scholger R \& Rey D 2003. Mapping dust distribution around an industrial site by measuring magnetic parameters of tree leaves. Atmospheric Environment 37: 36, 5125-5133. http:// dx.doi.org/10.1016/j.atmosenv.2003.07.013.

Hauck M \& Huneck S 2007. Lichen substances affect metal adsorption in Hypogymnia physodes. Journal of Chemical Ecology 33: 1, 219-223. http:// dx.doi.org/10.1007/s10886-006-9225-6.

Häffner E, Lomský B, Hynek V, Hällgren JE, Batic F \& Pfanz H 2001. Air pollution and lichen physiology. Water, Air, and Soil Pollution 131: 1-4, 185-201. http://dx.doi.org/10.1023/A:1011907530430.

Jordanova D, Petrov P, Hoffmann V, Gocht T, Panaiotu C, Tsacheva T \& Jordanova N 2010. Magnetic signature of different vegetation species in polluted environment. Studia Geophysica et Geodetica 54: 3, 417-442.

http://dx.doi.org/10.1007/s11200-010-0025-7.

Jussila I, Laihonen P \& Jormalainen V 1991. A bioindicator study on the effects of air pollution on forest ecosystem at Pori-Harjavalta district in SW Finland. Turun yliopisto, Satakunnan ympäristöntutkimuskeskus. Sykesarja B2, Pori, 62. (in Finnish)

Jussila I 2009. Porin-Harjavallan alueen sammalpallotutkimukset vuonna 2007. Turun yliopisto, Sa- takunnan ympäristöntutkimuslaitos. Tutkimusraportti 1/2009, Pori, 43. (in Finnish, with English summary)

Lehndorff E, Urbat M \& Schwark L 2006. Accumulation histories of magnetic particles on pine needles as function of air quality. Atmospheric Environment 40: 36, 7082-7096.

http://dx.doi.org/10.1016/j.atmosenv.2006.06.008.

Limo J 2010. Magnetic susceptibility of epiphytic lichen, Hypogymnia physodes, as an indicator of airborne heavy metal concentrations and air quality in the city area of Turku, Finland, in the year 2005. Unpublished master thesis. 79 p., 14 appendix p. Department of Geography, University of Turku. (in Finnish, abstract in English)

Little P \& Martin MH 1974. Biological monitoring of heavy metal pollution. Environmental Pollution 6: 1, 1-19.

http://dx.doi.org/10.1016/0013-9327(74)90042-1.

Loppi S \& Bonini I 2000. Lichens and mosses as biomonitors of trace elements in areas with thermal springs and fumarole activity (Mt. Amiata, central Italy). Chemosphere 41: 9, 1333-1336. http://dx. doi.org/10.1016/S0045-6535(00)00026-6.

Mikhailova IN 2007. Populations of epiphytic lichens under stress conditions: survival strategies. Lichenologist 39: 1, 83-89.

http://dx.doi.org/10.1017/S0024282907006305.

Mikhailova IN \& Sharunova IP 2008. Dynamics of heavy metal accumulation in thalli of the epiphytic lichen Hypogymnia physodes. Russian Journal of Ecology 39: 5, 346-352.

http://dx.doi.org/10.1134/S1067413608050068.

Mitchell R \& Maher BA 2009. Evaluation and application of biomagnetic monitoring of traffic-derived particulate pollution. Atmospheric Environment 43: 13, 2095-2103.

http://dx.doi.org/10.1016/j.atmosenv.2009.01.042.

National Land Survey of Finland 2010. Topographic Database 1:10 000.

Nieminen TM, Ulkomaanaho L \& Shotyk W 2002. Enrichment of $\mathrm{Cu}, \mathrm{Ni}, \mathrm{Zn}, \mathrm{Pd}$ and $\mathrm{As}$ in an ombrotrophic peat bog near a $\mathrm{Cu}-\mathrm{Ni}$ smelter in Southwest Finland. The Science of the Total Environment 292: 1-2, 81-89. http://dx.doi.org/10.1016/ S0048-9697(02)00028-1.

Palomäki V, Tynnyrinen S \& Holopainen T 1992. Lichen transplantation in monitoring fluoride and sulphur deposition in the surroundings of a fertilizer plant and a strip mine at Siilinjärvi. Annales Botanici Fennici 29: 1, 25-34.

Pilegaard K 1979. Heavy metals in bulk precipitation and transplanted Hypogymnia physodes and Dicranoweisia cirrata in the vicinity of a Danish steel works. Water, Air, and Soil Pollution 11: 1, 77-91. http://dx.doi.org/10.1007/BF00163521.

Salo H, Bucko MS, Vaahtovuo E, Limo J, Mäkinen J \& Pesonen LJ 2012. Biomonitoring of air pollution in SW Finland by magnetic and chemical measurements of moss bags and lichens. Journal of Geochemical Exploration 115, 69-81. http://dx.doi.org/10.1016/j.gexplo.2012.02.009. 
Salo H \& Mäkinen J 2014. Magnetic biomonitoring by moss bags for industry-derived air pollution in SW Finland. Atmospheric Environment 97, 19-27. http://dx.doi.org/10.1016/j.atmosenv.2014.08.003. Szczepaniak K \& Biziuk M 2003. Aspects of the biomonitoring studies using mosses and lichens as indicators of metal pollution. Environmental Research 93: 3, 221-230. http://dx.doi.org/10.1016/ S0013-9351(03)00141-5.
Thompson R \& Oldfield F 1986. Environmental magnetism. Allen \& Unwin Ltd., UK.

Wolterbeek B 2002. Biomonitoring of trace element air pollution: principles, possibilities and perspectives. Environmental Pollution 120: 1, 11-21.http:// dx.doi.org/10.1016/S0269-7491(02)00124-0. 